\title{
Article \\ Strategies for Effective Waste Reduction and Management of Building Construction Projects in Highly Urbanized Cities- A Case Study of Hong Kong
}

\author{
Ann T. W. Yu*D, Irene Wong, Zezhou Wu and Chi-Sun Poon
}

check for

updates

Citation: Yu, A.T.W.; Wong, I.;

$\mathrm{Wu}, \mathrm{Z}$; Poon, C.-S. Strategies for

Effective Waste Reduction and

Management of Building

Construction Projects in Highly Urbanized Cities-A Case Study of Hong Kong. Buildings 2021, 11, 214. https://doi.org/10.3390/

buildings 11050214

Academic Editor: Łukasz Sadowski

Received: 9 April 2021

Accepted: 12 May 2021

Published: 19 May 2021

Publisher's Note: MDPI stays neutral with regard to jurisdictional claims in published maps and institutional affiliations.

Copyright: (c) 2021 by the authors. Licensee MDPI, Basel, Switzerland. This article is an open access article distributed under the terms and conditions of the Creative Commons Attribution (CC BY) license (https:/ / creativecommons.org/licenses/by/ $4.0 /)$.
Department of Building and Real Estate, The Hong Kong Polytechnic University, Hung Hom, Hong Kong. irene.w@connect.polyu.hk (I.W.); wuzezhou@szu.edu.cn (Z.W.); chi-sun.poon@polyu.edu.hk (C.-S.P.)

* Correspondence: ann.yu@polyu.edu.hk

\begin{abstract}
Hong Kong is a densely populated city with high-rise developments, and as in other metropolitan cities, the amount of waste generated from construction projects in the city is increasing annually. The capacity of existing landfills is expected to be saturated by the 2020s. Construction waste management has been implemented for years but the performance is still not satisfactory. The aim of this research paper is to explore and formulate strategies and measures for effective construction waste management and reduction in highly urbanized cities such as Hong Kong. A desktop study on construction waste management practices was carried out for a preliminary understanding of the current situation in Hong Kong. Semistructured interviews and focus group meetings were further conducted to shed light on how to improve construction waste reduction and management in Hong Kong. The main contributions of this research study are the potential short-term, medium-term, and long-term strategies, which are related to the design stage, tender stage, construction stage, and government support. The five major strategies recommended are financial benefits to stakeholders, public policies in facilitating waste sorting, government supports for the green building industry, development of a mature recycling market, and education and research in construction waste minimization and management.
\end{abstract}

Keywords: waste reduction and management; on-site and off-site sorting; recycling and reuse; green building technologies; research and education

\section{Introduction}

Construction activities produce large quantities of solid waste daily from construction and demolition, which cause an adverse impact on our environment [1,2]. The collection, treatment, and disposal of solid waste, particularly in highly urbanized cities become a difficult problem to solve [3]. Both developed and developing countries such as the United States (US) and China are running short of landfill sites and facing a challenging problem of environmental degradation caused by construction waste seeking landfill sites for construction waste [2,4]. Hong Kong is one of the world's leading business centers. The population is more than 7.52 million living in about 1107 square kilometers with a high population density of 6793 people per square kilometer [5].

Construction waste of Hong Kong is mainly composed of a mixture of solid inert and noninert waste generated from excavation, site work, demolition, renovation and, civil and building projects [6,7]. Inert waste, which is composed mainly of paper, sand, wood, bricks, and concrete, are disposed of at three strategic municipal solid waste landfills and used as land reclamation materials [7-9]. Hong Kong cannot rely solely on reclamation to dispose of our inert construction waste for sustainable development [10]. From the Environmental Protection Department report [11], generation of construction waste in 2019 had only decreased by 3.3\% from 2018 amounting to 1.44 million tonnes and the reuse rate of inert materials had slightly increased by $2 \%$ to $92 \%$. Although parts of the inert waste 
particularly concrete aggregates have high reuse potential [4,12], the mixing of inert and noninert waste generated from construction works increases the difficulty of separation ending up in a large portion of inert waste at public filling areas and landfills [7]. Reuse of demolished concrete to substitute natural aggregates can solve the shortage problem of natural aggregates [13] and preserve valuable space in landfills [14]. "Preservation of the environment and conservation of the rapidly diminishing natural resources should be the essence of sustainable development" [12] (p. 72). Reviewing the practices of waste management indicated that the current strategies for waste reduction and management of building construction projects in a highly urbanized city of Hong Kong are not effective [15]. Hong Kong should develop and implement effective strategies to reduce and manage construction waste and handle the problem in a more environmentally responsible way [8].

The Hong Kong Polytechnic University had carried out a consultancy research project for the Construction Industry Council (CIC) exploring effective strategies for management and reduction of construction and demolition waste in Hong Kong and summarized in eight reports and a summary report. The aim of this paper is to develop and summarize short-term, medium-term, and long-term strategies to improve the effectiveness of waste management for building construction projects in highly urbanized cities such as Hong Kong. The novelty of this research paper is the categorization of the strategies according to the timeline of the building projects. This paper serves as a comprehensive collection of all the updated strategies for the government officials' and professional practitioners' reference to improve C\&D minimization and management.

\section{Literature Review: Current Practices of Construction Waste Management in Hong Kong}

The construction industry had disposed of an average of about 4000 tonnes ( $25 \%$ of total disposal) of C\&D waste at landfills per day in 2019. Most of the mixed construction is disposed of at sorting facilities or landfills without sorting. Our landfills and public fill capacity will be saturated by the 2020s according to the current trend of construction waste management [16]. The government is examining ways to reduce construction waste.

There are various strategies, approaches, and measures of construction waste management practicing in the public and private sectors. Poon and Poon et al. have identified seven effective good practices (see Sections 2.1-2.7) [8,17-19], which are recommended to be included in the strategies for construction waste management in highly urbanized cities. Other approaches such as circular economy, zero waste approach, and green rating system are also discussed in Sections 2.8-2.10.

\subsection{Construction Waste Disposal Charging Scheme (CWDCS)ConstructionC}

Since the implementation of CWDCS in 2005, the total waste generation had significantly reduced but the effectiveness started to decrease after three years [20-23]. The charging standard was increased in 2017 in order to improve the effectiveness of CWDCS, as illustrated in Table 1. Reducing disposal costs can create a significant incentive for the construction industry in reducing construction waste.

Table 1. Comparison of charging standards for construction waste disposal.

\begin{tabular}{cccc}
\hline Disposal Facilities & $\begin{array}{c}\text { Types Pf Construction Waste } \\
\text { Accepted }\end{array}$ & $\begin{array}{c}\text { Charge Standard in 2014 } \\
\text { (HKD) }\end{array}$ & $\begin{array}{c}\text { Charge Standard in 2017 } \\
\text { (HKD) }\end{array}$ \\
\hline Public fill reception facilities & $\begin{array}{c}\text { Consisting entirely of inert } \\
\text { construction waste }\end{array}$ & 27 & 71 \\
Sorting facilities & $\begin{array}{c}\text { Containing more than 50\% by weight } \\
\text { of inert construction waste } \\
\text { Containing not more than 50\% by } \\
\text { weight of inert construction waste }\end{array}$ & 100 & 175 \\
\hline
\end{tabular}




\subsection{Site Waste Management Plans}

Site waste management plan (SWMP) is becoming popular nowadays as a valuable approach for the purpose of assisting construction stakeholders to anticipate the type of $C \& D$ waste as well as estimate the quantity for making the right decisions in order to manage it [24]. A waste management plan is required for all public projects and has proved that reuse and recycling can be improved [9]. However, the effectiveness of SWMP is limited by site constraints and overhead costs [25]. The majority of sites do not have enough areas to carry out on-site sorting, which is labor intensive. The enforcement of SWMP is not common in private projects. It is necessary to provide more sorting facilities and explore the means to reduce overhead costs.

\subsection{Proper Design}

Appropriate design can avoid waste generation at the very beginning stage of construction works $[18,26]$, which includes dimensional coordination and standardization, minimizing the use of temporary works, design for use of recycled materials, avoiding late design modifications, applying low-waste building technologies, backfilling cut and fill by the excavated soils, modeling design information, etc. Zhang et al. and Baldwin et al. suggested that modeling design information flows could evaluate optimized design solutions $[27,28]$. However, lacking mandatory requirements in the green building assessment tool, designing out waste is not widely practicing in the construction industry [19]. Future research on how to properly designing out waste is necessary.

\subsection{Deconstruction}

Deconstruction, which is also called selective demolition, can effectively facilitate the reuse and recycling of construction waste [25,29]. Deconstruction is carried out reversing the construction processes requiring planned sorting of the demolished materials according to their categories so as to prevent contaminating the recyclable materials such as wood, paper, cardboard, plastic, metal, and concrete aggregates [29,30].

Expensive manual sorting and insufficient recycling outlets are deterring contractors from carrying out deconstruction. Concurrently the recycling market in Hong Kong is underdeveloped. A mature recycling market is essential to provide more outlets for recyclable items.

\subsection{Prefabrication and Modular Construction}

Prefabrication can reduce about $52 \%$ of construction waste by minimizing on-site wet trade and improving buildability and perform better than conventional construction methods in environmental, economic, and social aspects [15,19,31-34]. The Hong Kong Housing Authority has been a pioneer in using prefabrication in building housing estates. However, the implementation of prefabrication is not common in the private sector, and there is room for improvement. Furthermore, prefabrication has some disadvantages including less flexibility with plans and manufacturing, and limitation on transportation [35].

\subsection{On-Site and Off-Site Waste Sorting}

On-site sorting is effective in reducing construction waste and recover valuable materials for reuse and recycling thus reducing disposal costs [35]. However, contractors are reluctant to carry out on-site sorting in spite of high tipping costs due to congested site conditions, tight construction period, high labor demand, expensive operation costs, and lack of recycling outlets [7]. Off-site sorting can be an alternative to promote reuse and recycling since the operating costs can be less expensive than direct disposal at landfills [2]. It is necessary to develop more customized on-site recycling equipment and thriving offsite recycling [36]. How to select a proper location for off-site construction waste sorting facilities that can reduce transportation costs and prevent noise and dust is an important factor to be considered. 


\subsection{Reduce, Reuse and Recycling}

Most of the C\&D waste research is largely focused on the "three Rs" principle of waste (reduction, reuse, and recycling), also known as the waste hierarchy [24,37]. EPD has pointed out in a 2005 report that "the burden of Hong Kong's landfills can be reduced through reuse, recovery and recycling" [38] (chapter 1, point 9). Research on reusing waste glass as an aggregate in concrete or additive in cement pastes or mortar have been conducted [39-41]. Though recycling technologies have been developed in recent years, how to promote the use of recycled products is still an issue to be solved. In addition, changing an individual's recycling attitude and behavior is of utmost importance in achieving sustainable $C \& D$ waste reduction and management [42].

\subsection{Circular Construction}

Circular construction is based on the concept of a circular economy model, which tries to keep the products and materials "in flow" by means of effective reuse strategies, thus reducing the use of virgin materials and negative environmental impacts [43,44]. This can be accomplished using smart design and circular value chains, which is crucial for a sector to reduce both its waste and the amount of virgin resources used [45]. Transition to a circular construction involves changes in value chains, from building design, from new professional behavior to new ways of turning waste into a resource. It is necessary to promote $C \& D$ waste management guidelines in order to "contribute to resource efficiency and enable the transition from a Linear to a Circular Economy" [46] (p. 2).

\subsection{Zero Waste Approach}

Authorities need to look for alternative waste management systems due to the lack of landfill sites in urban areas. Zero waste (ZW), which is a perceptive system of waste management, has been introduced as an alternative solution for waste problems in recent decades in many cities such as San Francisco, Vancouver, and Adelaide [47]. ZW concept motivates sustainable consumption and production, optimization of resource recovery and recycling, and prevents wastes from incineration and landfilling [24]. Research conducted by Zaman and Lehmann proposed that a ZW city should recover $100 \%$ of its resources from waste and should reach a $100 \%$ recycling rate, although this is an ideal case [48].

\subsection{Green Rating System}

Green rating systems throughout the world are widely applied in order to assess the sustainability of construction processes. In Hong Kong, these sustainability assessment tools including Building Environmental Assessment Method Plus (BEAM Plus) and Leadership in Energy and Environmental Design (LEED). For instance, BEAM Plus New Buildings came to action in 2012; BEAM Plus Interiors (Commercial, Retail, and Institutional) was introduced in 2013; and BEAM Plus Existing Buildings (Comprehensive and Selective Scheme) was launched in 2016. The materials aspects in these standards and assessments address the issues of design approaches, selection and use of materials, as well as C\&D waste reduction.

\subsection{Research Gap}

Although there are many studies on the reduction and management of $C \& D$ waste, little attention has been paid to a comprehensive and holistic attempt to summarize all the updated strategies and measures in Hong Kong. The contributions of this work have been the classification of these strategies and measures in short, medium, and long terms, and the timelines of these strategies to be adopted under design, tender, and construction stages. These findings formulate a good reference for the government since it needs to support the construction industry in C\&D waste reduction and management. 


\section{Research Methods}

In this paper, a combination of literature review, personal interviews, and focus group meetings was used for achieving the research aim. After completion of the research design and pilot study, construction practitioners were interviewed in the second stage to collect their expertise comments on construction waste reduction and management. The interview questions were formulated based on the literature review. In the third stage, the summary of the interviews was presented at two focus group meetings, followed by discussing the interview findings and encouraging the participants to propose strategies on effective waste reduction and management of building construction projects in highly urbanized cities.

\subsection{Desktop Study}

A desktop study on scholarly papers, government websites, and the nine reports produced by the Hong Kong Polytechnic University from the consultancy project [5] formed the reference materials for this research. The desktop study was carried out covering the literature from 2000 to 2020. The type of database/e-resource used included Web of Science, Scopus, Science Direct, and Google Scholar. A list of terms for searching included construction and demolition waste, waste management, construction waste, demolition waste, etc. Successful overseas and local examples of construction waste management policies and measures were identified for analysis. An evaluation of Hong Kong's current construction waste management was also conducted to provide background information for this research. Current good practices and limitations of construction waste management were identified and summarized in Section 2. The literature review took two months to be completed and summarized for formulating the issues to be discussed during interviews and focus group meetings.

\subsection{Personal Interviews}

The interviews were carried out in the participants' offices in 2016. A set of interview questions was formulated from the findings of the literature review. The interview guide is attached to Appendix A. The research team has visited 20 construction industry practitioners including two developers, four architects, one building surveyor, three main contractors, one demolition contractor, and six representatives from Architectural Services Department, Civil Engineering and Development Department, Development Bureau, Environmental Protection Department, and Housing Department in 12 interviews. The sample size is usually small in qualitative research, which is within 15 to 20 when the point of diminishing return occurs [49-52]. The aim of the interview was to collect professional views and comments on the current construction waste management practices and propose improvement. The questions focused on the implementation of waste management in public and private sectors, the incurred barriers and difficulties in implementing, strategies and measures for improvement, recommendations to the government, and the effectiveness of enforcing BEAM Plus to facilitate waste management. Interviewees were invited to share their success stories in construction waste management. They were also invited to define the roles of client, designer, and contractor in construction waste management. The main concern of clients/developers is the amount of revenue return. Designers shared their valuable experiences on construction waste management, while contractors voiced out their encountered difficulties during implementation. Government officials shed light on the principles of construction waste management legislation. The duration of the interviews ranged from half an hour to one hour. The interviews were recorded with a mobile phone and subsequently translated into English for the written transcript.

\subsection{Focus Group Meetings}

The findings from the literature review and interviews were discussed in two focus group meetings. The focus group participants included architect, surveyor, main contractor, SME contractor, Housing Department, Environmental Protection Department, Civil Engineering and Drainage Department, and Hong Kong Green Building Council. There 
were eight participants in each of the focus groups. The meetings were begun with the presentation of findings by the authors. The participants then shared their insight into construction minimization and management strategies.

The conversations in the meetings were recorded with a recording pen and subsequently translated into English for the written transcript. The summary of findings and suggestions from the two focus groups on reducing $C \& D$ waste and improving construction waste management are discussed in Sections 4.1 and 4.2.

\section{Research Findings from Interviews and Focus Group Meetings}

\subsection{Barriers and Difficulties in Construction Waste Management}

The main barriers and difficulties in construction waste management are low incentive of clients due to high initial cost, congested site for carrying out on-site sorting, high recycling cost, worry about the quality of recycled products, immature recycling market, insufficient skilled recycling labor, the low penalty of illegal dumping compared to the cost of recycling, inadequate government support, and low accreditations for recycling in BEAM Plus, which are tabulated in Table 2.

Table 2. Barriers and difficulties in construction waste management.

\begin{tabular}{|c|c|}
\hline Barriers/Difficulties & Causes \\
\hline Clients' low incentive & $\begin{array}{l}\text { Labor and time consuming, which incur high initial cost deter clients to consider } \\
\text { adopting waste management practices. }\end{array}$ \\
\hline Composite site condition & Insufficient space for on-site sorting and temporary storage of sorted waste. \\
\hline High recycling cost & $\begin{array}{c}\text { Labor and transportation costs of recycling construction waste are high } \\
\text { particularly for timber and concrete. }\end{array}$ \\
\hline Quality of recycled materials & Lacking standardization of quality. \\
\hline Immature recycling market & $\begin{array}{c}\text { There are few local recycling companies especially for timber and concrete } \\
\text { resulting in high recycling costs }\end{array}$ \\
\hline Insufficient skilled labors & Insufficient skilled labors to handle aluminum formwork. \\
\hline Illegal dumping & $\begin{array}{l}\text { Some public filling areas are too remote and under-utilized. } \\
\text { Penalties of illegal dumping are insionificant comparing to contract sums. }\end{array}$ \\
\hline $\begin{array}{c}\text { Inadequate government support to green } \\
\text { technology }\end{array}$ & $\begin{array}{l}\text { Conservative attitude of Government in approving innovative green technologies. } \\
\text { Lengthy and complicated approving procedure. }\end{array}$ \\
\hline Influence of BEAM Plus & $\begin{array}{l}\text { The low achievement to satisfy the stringent requirements of } 60 \% \text { of recycling } \\
\text { construction waste for accrediting only } 2 \text { credits. } \\
\text { Discouraging minimizing use of steel, reuse excavated soil for backfilling, } \\
\text { revitalize and reuse existing foundation and structural framework, revise method } \\
\text { statement according to site conditions for reducing abortive work as these } \\
\text { attempts are not considered for accreditation. } \\
\text { Lack of monitoring system for compliance with accreditation requirements. }\end{array}$ \\
\hline
\end{tabular}

\subsection{Suggestions}

According to the findings from the literature review, interviews, and focus group meetings, suggestions to improve construction waste management were categorized into four main aspects: design stage, tender stage, construction stage, and government support, which are summarized in Table 3. These suggestions formed the guidelines for exploring strategies for effective construction waste management in an urbanized city. 
Table 3. Suggestions for improving construction waste management.

\begin{tabular}{|c|c|c|c|}
\hline & Findings from Literature Review & Suggestions from Interviews & $\begin{array}{c}\text { Suggestions from Focus Group } \\
\text { Meetings }\end{array}$ \\
\hline Design Stage & $\begin{array}{l}\text { Dimensional coordination, } \\
\text { standardization, } \\
\text { design for use of recycled materials, } \\
\text { avoiding late design modifications } \\
\text { and modeling design information, } \\
\text { use of prefabrication }\end{array}$ & $\begin{array}{c}\text { Consider using waste-reducing design } \\
\text { and technologies early in the design } \\
\text { stage. } \\
\text { Use "integrated project design" } \\
\text { involving multi-disciplines to reduce } \\
\text { abortive work. } \\
\text { Apply BIM to reduce crashes in } \\
\text { construction processes. }\end{array}$ & $\begin{array}{c}\text { Apply adaptable design, no-frill design, } \\
\text { use precast and prefabrication } \\
\text { technologies, standard and modular } \\
\text { units. } \\
\text { Reuse existing building foundation and } \\
\text { structure. } \\
\text { Use reusable formwork, sustainable and } \\
\text { recycling materials, and drywall } \\
\text { systems. }\end{array}$ \\
\hline Tender Stage & Waste management plans & $\begin{array}{c}\text { Introducing contractual "recycle rates" } \\
\text { and "Award and Penalty Scheme" in } \\
\text { the tender document. } \\
\text { Allow contractors to propose EMP } \\
\text { and award contactors for meeting } \\
\text { defined goals. } \\
\text { Penalty for noncompliance. }\end{array}$ & $\begin{array}{l}\text { Using "Design and Build" contracts in } \\
\text { infrastructure projects to help formulate } \\
\text { custom-designed WMP to suit site } \\
\text { conditions. } \\
\text { A percentage of contact sum to be set } \\
\text { aside as a bonus award to contactors for } \\
\text { meeting targeted goals in construction } \\
\text { waste management. }\end{array}$ \\
\hline Construction Stage & $\begin{array}{l}\text { Minimizing the use of temporary } \\
\text { works, applying low-waste building } \\
\text { technologies, backfilling cut and fill } \\
\text { by the excavated soils, } \\
\text { On-site sorting and off-site sorting }\end{array}$ & $\begin{array}{c}\text { Allow longer construction periods for } \\
\text { implementing WMP. } \\
\text { Carry out construction work in phases } \\
\text { to facilitate reusing temporary works. } \\
\text { Setting up communication platforms } \\
\text { among contractors for coordinating } \\
\text { reuse and recycling construction } \\
\text { waste. }\end{array}$ & $\begin{array}{l}\text { Clients should allow sufficient time for } \\
\text { the application of Occupation Permit to } \\
\text { avoid using temporary provisions to } \\
\text { satisfy the issuing requirements. }\end{array}$ \\
\hline Government Support & $\begin{array}{l}\text { Construction waste disposal } \\
\text { charging scheme }\end{array}$ & $\begin{array}{l}\text { Promote the application and } \\
\text { development of green construction } \\
\text { technologies and materials. } \\
\text { Encourage contractors to } \\
\text { reuse/recycle construction waste. } \\
\text { Facilitate local development of } \\
\text { recycling and prefabrication } \\
\text { industries. } \\
\text { Public education on the importance of } \\
\text { reducing and recycling construction } \\
\text { waste.Public consultation to collect } \\
\text { suggestions for effective construction } \\
\text { waste management. }\end{array}$ & $\begin{array}{c}\text { Provide low-rent sites for setting up the } \\
\text { prefabrication industry. } \\
\text { To utilize incinerator at Tuen Mun for } \\
\text { burning timber waste or allow the use of } \\
\text { waste-derived fuel in the industry. } \\
\text { Building Department to consider } \\
\text { re-classifying extensive reuse of existing } \\
\text { building under New Building category } \\
\text { to encourage revitalization projects. } \\
\text { Create more public off-site sorting } \\
\text { spaces. } \\
\text { Privatize the management of the current } \\
\text { government-run waste sorting sites } \\
\text { enabling market forces to initiate the } \\
\text { development of the recycling industry. } \\
\text { Create a variety of recycling outlets. } \\
\text { Large-scale increase in waste disposal } \\
\text { charges suggested being HKD 500/ton. } \\
\text { Coordinate with CIC and Hong Kong } \\
\text { Green Building Council (HKGBC) to } \\
\text { streamline the approval of low-waste } \\
\text { technologies and reusable materials. } \\
\text { HKGBC to review BEAM Plus } \\
\text { accreditation for reducing construction } \\
\text { waste in a passive manner. } \\
\text { To standardize the quality of recycled } \\
\text { materials }\end{array}$ \\
\hline
\end{tabular}

\section{Proposed Strategies for Promoting Construction Waste Reduction and Management in Hong Kong}

Planning and policies can be divided into short, medium, and long terms. Gartenstein has clearly elaborated the functions of short-, medium-, and long-term planning [53]. Short-term objectives are geared towards short-term needs and should serve the long-term goals. Medium-term planning brings together the clarity of shorter-term goals with the depth of longer-term planning. Long-term plans are concrete means to express a larger vision and adjusted over time as the medium-term situation unfolds. Proposed strategies promoting construction waste management in Hong Kong can also be classified as short 
(S), medium (M), and long (L) terms. Short-term strategies relate to readily available means. Medium-term strategies enhance the development of existing good practices in construction waste management. Long-term strategies are mostly associated with public policies, research, and education. Success in implementing construction waste reduction and management requires the participation and cooperation of clients, designers, contractors, government, and the general public. The following sections discuss the proposed strategies for construction stakeholders and government according to design stage, tender stage, construction stage, and government support.

\subsection{Proposed Strategies for Construction Stakeholders}

The proposed strategies for effective construction waste reduction and management concern clients, building designers, contractors, and the government relating to the five main strategies in the design stage, tender stage, construction stage, and government support, which cover financial benefits to stakeholders, public policies in facilitating waste sorting, government supports for the green building industry, development of a mature recycling market, and education and research in construction waste management.

\subsubsection{Design Stage}

According to the hierarchy model proposed by Peng et al. [4], the most effective mean of construction waste reduction is to reduce at the source. SWMP should be included in the early design stage, considering the application of no-frills and fuss-free design and using low-waste building technologies. Low-waste building technologies include precast/prefabrication, standard/modular and adaptive design, reuse of existing building foundations and structures, reusable temporary works, sustainable/recyclable building materials, drywall systems, etc. Setting up an "integrated project design" including multiple disciplines at the design stage can minimize abortive works. "Design and build" contract can enable contractors to formulate SWMP tailor-made for their company management and site conditions. Building Information Modeling (BIM) can help to review the crashes in virtual construction sequences, which can avoid abortive work.

\subsubsection{Tender Stage}

Implementation of SWMP can be specified in the tender stage. Introducing contractual "recycling rates" and "award and penalty" schemes in tender documents can create incentives for reducing construction waste. The tender can offer a certain percentage of the contract sum as a bonus for contractors who can achieve the waste reduction target in the SWMP. Contractors will be awarded for meeting the target and penalized for noncompliance. Usually, different construction trades are working simultaneously in a congested site making it difficult to carry out on-site sorting. Clients can allow a slightly longer construction period for on-site sorting. A longer construction period can also optimize the reuse of temporary work. Off-site sorting can be included when there is not sufficient storage space. Contractors should be encouraged to set up a communication platform for coordinating the reuse and recycling of construction waste among the industry.

\subsubsection{Construction Stage}

Table 4 categorized the suggested measures of improving construction waste management for different stakeholders according to design, tender, and construction stage in short-, medium-, and long-term implementation timeframe, which can serve as guidelines in formulating short-term, medium-term, and long-term construction waste management strategies. 
Table 4. Proposed strategies for construction stakeholders.

\begin{tabular}{|c|c|c|c|c|}
\hline Measures & Client & Designer & Contractor & $\begin{array}{l}\text { Implementation Time } \\
\text { Frame }\end{array}$ \\
\hline \multicolumn{5}{|l|}{ Design Stage } \\
\hline No-Frills Design & $x$ & $x$ & & M \\
\hline Adaptive design & $x$ & $x$ & & M \\
\hline Integrated Project Design & & $x$ & $X$ & M \\
\hline Consider waste reduction and management & $x$ & $x$ & & M \\
\hline $\begin{array}{l}\text { Use Design and Build contract for } \\
\text { infrastructure projects }\end{array}$ & $x$ & $x$ & $\mathrm{X}$ & M \\
\hline Low-waste technologies & $x$ & $\mathrm{X}$ & & $\mathrm{S} / \mathrm{M}$ \\
\hline $\begin{array}{l}\text { Use precast concrete/prefabricated building } \\
\text { components }\end{array}$ & $X$ & $X$ & & $\mathrm{~S}$ \\
\hline Reuse existing foundation/structures & $x$ & $x$ & & $\mathrm{~S}$ \\
\hline Use reusable temporary work & & $x$ & & $S$ \\
\hline Use dry wall system and external painting & $x$ & $x$ & & $\mathrm{~S}$ \\
\hline Use durable/recycled building materials & $x$ & $x$ & & $\mathrm{~S}$ \\
\hline Minimize design revision & $x$ & $x$ & & $\mathrm{~S}$ \\
\hline Apply BIM to review construction sequences & & $x$ & & $\mathrm{~S}$ \\
\hline \multicolumn{5}{|l|}{ Tender Stage } \\
\hline Introduce "Award and Penalty" scheme & $x$ & $x$ & $x$ & $\mathrm{M}$ \\
\hline $\begin{array}{l}\text { Contractors propose innovative waste } \\
\text { management scheme }\end{array}$ & $x$ & $x$ & $x$ & M \\
\hline $\begin{array}{l}\text { Introduce waste reduction procurement for } \\
\text { nominated subcontracts }\end{array}$ & $x$ & $x$ & $x$ & M \\
\hline Allow recycling rates in $\mathrm{BQ}$ & $x$ & $x$ & $x$ & $S$ \\
\hline \multicolumn{5}{|l|}{ Construction Stage } \\
\hline $\begin{array}{l}\text { Setup contractor communication platform for } \\
\text { reuse and recycling }\end{array}$ & & & $x$ & $\mathrm{~L}$ \\
\hline Allow longer construction period & $x$ & & & M \\
\hline Review Method Statement for Construction & & $x$ & $x$ & M \\
\hline Better phasing construction period & & $x$ & $x$ & $\mathrm{~S}$ \\
\hline Onsite/off-site sorting & & & $x$ & $S$ \\
\hline $\begin{array}{l}\text { Consider off-site sorting when onsite sorting } \\
\text { is not feasible }\end{array}$ & & & $x$ & $\mathrm{~S}$ \\
\hline Reuse excavated soil in other projects & & & $x$ & $\mathrm{~S}$ \\
\hline $\begin{array}{l}\text { Reuse demolished concrete for paving bicycle } \\
\text { tracks }\end{array}$ & & & $x$ & S \\
\hline
\end{tabular}

$\mathrm{S}=$ short term; $\mathrm{M}=$ medium tern; $\mathrm{L}=$ long term.

\subsection{Recommendations to the Government}

Cost effectiveness is a significant factor that influences the stakeholders' waste management behavior and the government plays a significant role in promoting construction waste management [54]. In the focus group meetings, contractors argued that construction waste management was not a priority issue since most clients were not interested in reducing waste. Clients explained that they were not interested because the requirements for accrediting $30 \%$ and $60 \%$ of recycling construction waste in BEAM Plus were too stringent and contributing to only 1 credit and 2 credits, respectively [19]. Moreover, the requirements of reuse and recycling construction waste in demolition projects were not stated comprehensively and impractical. Beam Plus provides a significant financial incentive to clients in terms of gross floor area concession in achieving certain accreditations. However, other viable methodologies and passive measures for reducing construction waste are not considered for accreditation in BEAM Plus, such as reducing the use of steel, backfilling, revitalizing and reuse of existing foundation and structural framework, revising method statements to address different site conditions to reduce abortive work [19]. Furthermore, 
a monitoring system for implementing SWMP is lacking. The Government can advise HKGBC to review the BEAM Plus scoring system.

The recycling industry is poorly developed without adequate government support. Currently, there are only two concrete and one timber recycling companies. The capacity of recycling contractors could not cope with the amount of waste produced, which led to high recycling costs. Waste sorting can help to increase recycling rates. However, the high labor and transportation costs of recycling have impeded recycling. It is suggested to facilitate off-site sorting by providing more public waste sorting sites, which is recommended to be located adjacent to landfill in a 1:1 ratio. Government can consider privatizing the management of waste sorting facilities to assist the recycling market in creating momentum for development. In addition, the penalty for illegal dumping is insignificant, compared to the cost of minimizing construction waste. Some interviewees suggested a drastic increase in waste disposal charges, e.g., $\mathrm{HK} \$ 500$ /ton could significantly reduce construction waste or provide incentives to perform off-site sorting. Government can streamline the application for recycling subsidies and let out more short-term tenancy land to promote the development of local recycling industries. The recycling cost will be reduced when more recycling outlets are available. Therefore, policy to provide financial incentives for the setting up of local recycling industries should be explored.

The government also has an obligation to promote green technologies. The government should be more proactive in approving innovative green technologies. The Building Department (BD) can work with the CIC to conduct training classes for workers using the new technologies. The Building Department can consider reclassifying the extensive reuse of existing buildings under "New Buildings" instead of "Alteration and Addition Works" to facilitate flexibility in design.

Other major sources of construction waste include packaging materials and timber. Recyclable plastic packages and timber waste offer economic value to recycling contractors. Mandatory selective sorting of plastic and timber waste can initiate contractors into solving the waste sorting problem arising from site constraints. Since $50 \%$ of construction waste is unrecyclable contaminated timber formwork, it can be incinerated and turned to electrical energy to operate the incinerators or other local industries.

The suggestions for the government to promote effective construction waste reduction and management are summarized in Table 5. 
Table 5. Proposed measures for government/public organizations to reduce construction waste.

\begin{tabular}{|c|c|}
\hline Proposed Actions & Implementation Timeframe \\
\hline \multicolumn{2}{|l|}{ Interim Measures } \\
\hline Use waste to energy technology to burn timber waste for energy recovery. & $\mathrm{S}$ \\
\hline Promote green technologies and materials & \\
\hline Setup a central coordinating team for approving alternative recyclable/reusable materials. & M \\
\hline Simplify and streamline the approval process of innovative waste-reducing technologies. & M \\
\hline Streamline approving process of low-waste technologies and reusable materials. & M \\
\hline \multicolumn{2}{|l|}{ Encourage reuse/recycling of C\&D waste } \\
\hline Significant increase in waste disposal charges. & S \\
\hline Mandate selective onsite sorting for timber and plastic wastes. & M \\
\hline Mandate the use of reusable formwork & M \\
\hline $\begin{array}{l}\text { Introduce stronger incentives to encourage the recycling of construction waste in green } \\
\text { building rating schemes. }\end{array}$ & M \\
\hline Set up C\&D waste reduction policy and monitor implementation. & $\mathrm{L}$ \\
\hline Set up recycle standards and study implementation methods. & $\mathrm{L}$ \\
\hline Help explore potential markets on recyclable materials. & $\mathrm{L}$ \\
\hline Review and revise the scoring system of the green building rating system. & $\mathrm{L}$ \\
\hline \multicolumn{2}{|l|}{ Facilitate the development of the recycling industry } \\
\hline Streamline and simplify the approval process of recycling subsidies. & $\mathrm{M}$ \\
\hline Provide more public waste sorting sites. & M \\
\hline Privatize the sorting facilities to let the market decide the appropriate development patterns. & $\mathrm{L}$ \\
\hline Publicize the potential of lining up with recycling factories in Mainland China. & $\mathrm{L}$ \\
\hline \multicolumn{2}{|l|}{ Facilitate the development of local prefabrication industry } \\
\hline Award Gross Floor Area concession for precast/prefabricated façade. & M \\
\hline Provide low-rent sites for manufacturing. & M \\
\hline \multicolumn{2}{|l|}{ Research and Education } \\
\hline Set up research funding for construction waste reduction and management. & $\mathrm{L}$ \\
\hline Educate clients and contractors on the social responsibility of reducing construction waste. & $\mathrm{L}$ \\
\hline Educate the general public on the importance and necessity to minimize construction waste. & $\mathrm{L}$ \\
\hline
\end{tabular}

$\mathrm{S}=$ short term; $\mathrm{M}=$ medium tern; $\mathrm{L}=$ long term.

\section{Conclusions}

Construction waste management has been implemented for years in Hong Kong, but the performance is still not satisfactory. Government and building professionals are willing to work out effective strategies for construction waste reduction and management. Economic consideration is the dominating factor for success. Successful overseas examples in construction waste management involve legislation, high landfill tax, development of a mature recycling market, efficient platform for waste exchange, and a comprehensive credit-earning building environmental assessment system. Barriers to effective construction waste management and reduction were identified from interviews and focus group meetings, which were related to high overhead cost versus low economic return, inadequate government support, and incomprehensive coverage of waste management measures in the accreditation offered by BEAM Plus. Focus group discussions were conducted to explore potential strategies for effective construction waste reduction and management. Clients, designers, and contractors should cooperate with each other to improve waste management practices. Government facilitation and public support are also crucial factors of success. The proposed strategies were divided into short, medium, and long terms. From the research findings, 4 short-term strategies consisting of 22 measures, 5 mediumterm strategies comprising 14 measures, and 5 long-term strategies with 11 measures were developed, which relate to the five main strategies in the design stage, tender stage, construction stage, and government support. The strategies include financial benefits to stakeholders, public policies in facilitating waste sorting, government support for the green building industry, development of a mature recycling market, and education and research in construction waste management. 
Author Contributions: Conceptualization, C.-S.P.; methodology, A.T.W.Y.; data curation, A.T.W.Y., Z.W. and I.W.; writing-original draft preparation, I.W.; writing-review and editing, A.T.W.Y., supervision, C.-S.P. All authors have read and agreed to the published version of the manuscript.

Funding: This research was funded by The Hong Kong Polytechnic University (Project of Strategic Importance and G-YBQD), as well as the Construction Industry Council.

Institutional Review Board Statement: Not applicable.

Informed Consent Statement: Informed consent was obtained from all subjects involved in the study.

Data Availability Statement: New data were created or analyzed in this study. Data will be shared upon request and consideration of the authors.

Acknowledgments: The work described in this paper was supported by two grants from The Hong Kong Polytechnic University (Project of Strategic Importance) and G-YBQD, as well as the Construction Industry Council. The authors are grateful for all of the respondents participating in the interviews and focus group meetings, without whom, this research would not have been possible.

Conflicts of Interest: The authors declare no conflict of interest.

$\begin{array}{ll}\text { Abbreviations } \\ \text { BD } & \text { Building Department } \\ \text { BEAM Plus } & \text { Building Environmental Assessment Method Plus } \\ \text { BIM } & \text { Building Information Modeling } \\ \text { CIC } & \text { Construction Industry Council } \\ \text { CWDCS } & \text { Construction Waste Disposal Charging Scheme } \\ \text { EPD } & \text { Environmental Protection Department } \\ \text { HKGBC } & \text { Hong Kong Green Building Council } \\ \text { LEED } & \text { Leadership in Energy and Environmental Design } \\ \text { UNEP } & \text { United Nations Environment Program } \\ \text { SWMP } & \text { Site Waste Management Plans }\end{array}$

\section{Appendix A}

Interview Guide

1. Please furnish us with successful stories of $C \& D$ waste management and reduction in your organization.

2. What are your concerns on $C \& D$ waste management and reduction practices in Hong Kong?

3. What are the barriers and difficulties to $C \& D$ waste management and reduction practices in Hong Kong?

4. What are the strategies and measures for improving C\&D waste management and reduction practices in Hong Kong?

5. What should the HK Government do to take the lead and facilitate the C\&D waste reduction and management?

6. What should the clients do to promote C\&D waste reduction and management in Hong Kong?

7. What should the designers do to facilitate the C\&D waste minimization in the design stage as well as and to supervise the C\&D waste management of contractor in the construction stage?

8. What should the contractor do to reduce and management C\&D waste prevention, reduction and management on site?

9. What is the concern you have regarding the BEAM Plus requirements on the C\&D Waste Management? Whether the requirements are too stringent? Or more promotion/incentive is required? 


\section{References}

1. Osmani, M.; Glass, J.; Price, A. Architects' perspectives on construction waste reduction by design. Waste Manag. 2008, 28, 1147-1158. [CrossRef] [PubMed]

2. Lu, W.; Yuan, H. Off-site sorting of construction waste: What can we learn from Hong Kong? Resour. Conserv. Recycl. 2012, 69, 100-108. [CrossRef]

3. United Nations Environment Program (UNEP). Principles of Solid Waste Management; United Nations Environment Program: Nairobi, Kenya, 2005.

4. Peng, C.-L.; Scorpio, D.E.; Kibert, C.J. Strategies for successful construction and demolition waste recycling operations. Constr. Manag. Econ. 1997, 15, 49-58. [CrossRef]

5. World Population Review. Hong Kong Population 2020. Available online: https://worldpopulationreview.com/countries/hongkong-population/ (accessed on 9 April 2020).

6. Environmental Protection Department (EPD). Strategic Landfills. 2017. Available online: http://www.epd.gov.hk/epd/english/ environmentinhk/waste/prob_solutions/msw_strategic.html (accessed on 12 April 2018).

7. Poon, C.S.; Yu, A.T.; Ng, L. On-site sorting of construction and demolition waste in Hong Kong. Resour. Conserv. Recycl. 2001, 32, 157-172. [CrossRef]

8. Poon, C.S.; Yu, A.T.W.; Ng, L.H. A Guide for Managing and Minimizing Building and Demolition Waste; The Hong Kong Polytechnic University: Hung Hom, Kowloon, 2001; ISBN 962-367-311-6.

9. Tam, V.W. On the effectiveness in implementing a waste-management-plan method in construction. Waste Manag. 2008, 28, 1072-1080. [CrossRef] [PubMed]

10. Environmental Protection Department (EPD). Future Landfill Development in Hong Kong: View-Sharing Meeting on 2 March 2002. 2017. Available online: http://www.epd.gov.hk/epd/english/environmentinhk/waste/pub_consult/landfill_backgr_ r01.htm (accessed on 11 March 2018).

11. Environmental Protection Department (EPD). Monitoring of Solid Waste in Hong Kong, Waste Statistics for 2019. Statistic Unit, EPD, Hong Kong. 2020. Available online: https://www.wastereduction.gov.hk/sites/default/files/msw2019.pdf (accessed on 7 May 2020).

12. Rao, A.; Jha, K.N.; Misra, S. Use of aggregates from recycled construction and demolition waste in concrete. Resour. Conserv. Recycl. 2007, 50, 71-81. [CrossRef]

13. Khalaf, F.M.; Devenny, A.S. Recycling of demolished masonry rubble as coarse aggregate in concrete: Review. J. Mater. Civ. Eng. 2004, 16, 331-340. [CrossRef]

14. Schlender, R.M.; Bruckner, R.H. Setting up for recovery of construction and demolition waste. Solid Waste Power 1993, 7, $28-34$.

15. Tam, V.W.; Shen, L.; Fung, I.W.; Wang, J. Controlling construction waste by implementing governmental ordinances in Hong Kong. Constr. Innov. 2007, 7, 149-166. [CrossRef]

16. Environmental Protection Department (EPD). Introduction to Construction Waste (2020). Available online: https: / / www.epd.gov. $\mathrm{hk} / \mathrm{epd} / \mathrm{misc} / \mathrm{cdm} /$ introduction.htm (accessed on 7 May 2020).

17. Poon, C.S. Management of construction and demolition waste. Waste Manag. 2007, 27, 159-160. [CrossRef]

18. Poon, C.S. Reducing construction waste. Waste Manag. 2007, 27, 1715-1716. [CrossRef]

19. Construction and Industry Council (CIC). Report on Strategy for Management and Reduction of Construction and Demolition Waste in Hong Kong Version 1, August 2017. Available online: http:/ /www.cic.hk/files/page/56/C\%26D\%20Report_E.pdf (accessed on 7 April 2020).

20. Hao, J.L.; Hill, M.J.; Shen, L.Y. Managing construction waste on-site through system dynamics modelling: The case of Hong Kong. Eng. Constr. Arch. Manag. 2008, 15, 103-113. [CrossRef]

21. Hao, J.L.; Tam, V.W.Y.; Yuan, H.P.; Wang, J.Y. Construction waste challenges in Hong Kong and pearl river delta region. Int. J. Constr. Manag. 2011, 11, 37-47. [CrossRef]

22. Yuan, H.; Shen, L. Trend of the research on construction and demolition waste management. Waste Manag. 2011, 31, 670-679. [CrossRef]

23. Yu, A.T.; Poon, C.; Wong, A.; Yip, R.; Jaillon, L. Impact of construction waste disposal charging scheme on work practices at construction sites in Hong Kong. Waste Manag. 2013, 33, 138-146. [CrossRef] [PubMed]

24. Kabirifar, K.; Mojtahedi, M.; Wang, C.; Tam, V.W. Construction and demolition waste management contributing factors coupled with reduce, reuse, and recycle strategies for effective waste management: A review. J. Clean. Prod. 2020, 263, 121265. [CrossRef]

25. Poon, C.S.; Yu, A.T.W.; Wong, S.W.; Cheung, E. Management of construction waste in public housing projects in Hong Kong. Constr. Manag. Econ. 2004, 22, 675-689. [CrossRef]

26. Wu, Z.; Yu, A.T.; Shen, L.; Liu, G. Quantifying construction and demolition waste: An analytical review. Waste Manag. 2014, 34, 1683-1692. [CrossRef] [PubMed]

27. Zhang, X.; Wu, Y.; Shen, L. Application of low waste technologies for design and construction: A case study in Hong Kong. Renew. Sustain. Energy Rev. 2012, 16, 2973-2979. [CrossRef]

28. Baldwin, A.; Poon, C.-S.; Shen, L.-Y.; Austin, S.; Wong, I. Designing out waste in high-rise residential buildings: Analysis of precasting methods and traditional construction. Renew. Energy 2009, 34, 2067-2073. [CrossRef]

29. Poon, C.S. Management and recycling of demolition waste in Hong Kong. Waste Manag. Res. 1997, 15, 561-572. [CrossRef] 
30. Lauritezen, E.K.; Hahn, N.J. Building waste generation and recycling. In International Solid Waste Management Association Year Book 1991-1992; Union of International Associations: Cambridge, UK, 1992; pp. 48-58.

31. Li, Z.; Shen, Q.; Xue, X. Critical review of the research on the management of prefabricated construction. Habitat Int. 2014, 43, 240-249. [CrossRef]

32. Jaillon, L.; Poon, C.S. Sustainable construction aspects of using prefabrication in dense urban environment: A Hong Kong case study. Constr. Manag. Econ. 2008, 26, 953-966. [CrossRef]

33. Jaillon, L.; Poon, C.; Chiang, Y. Quantifying the waste reduction potential of using prefabrication in building construction in Hong Kong. Waste Manag. 2009, 29, 309-320. [CrossRef] [PubMed]

34. Chiang, Y.-H.; Chan, E.H.-W.; Lok, L.K.-L. Prefabrication and barriers to entry-A case study of public housing and institutional buildings in Hong Kong. Habitat Int. 2006, 30, 482-499. [CrossRef]

35. Tam, V.W.; Tam, C. Evaluations of existing waste recycling methods: A Hong Kong study. Build. Environ. 2006, 41, 1649-1660. [CrossRef]

36. Bao, Z.; Lee, W.M.; Lu, W. Implementing on-site construction waste recycling in Hong Kong: Barriers and facilitators. Sci. Total. Environ. 2020, 747, 141091. [CrossRef] [PubMed]

37. Osmani, M.; Villoria-Sáez, P. Current and emerging construction waste management status, trends and approaches. Waste 2019, 365-380. [CrossRef]

38. Environmental Protection Department (EPD). A Policy Framework for the Management of Municipal Solid Waste (2005-2014) 2005. Available online: http://www.epd.gov.hk/epd/msw/htm_en/illustrations/main.htm (accessed on 31 July 2018).

39. Ling, T.-C.; Poon, C.-S.; Wong, H.-W. Management and recycling of waste glass in concrete products: Current situations in Hong Kong. Resour. Conserv. Recycl. 2013, 70, 25-31. [CrossRef]

40. Duan, Z.H.; Poon, C.S. Properties of recycled aggregate concrete made with recycled aggregates with different amounts of old adhered mortars. Mater. Des. 2014, 58, 19-29. [CrossRef]

41. Lu, J.-X.; Duan, Z.-H.; Poon, C.S. Fresh properties of cement pastes or mortars incorporating waste glass powder and cullet. Constr. Build. Mater. 2017, 131, 793-799. [CrossRef]

42. Mak, T.M.; Iris, K.M.; Wang, L.; Hsu, S.C.; Tsang, D.C.; Li, C.N.; Poon, C.S. Extended theory of planned behaviour for pro-moting construction waste recycling in Hong Kong. Waste Manag. 2019, 83, 161-170. [CrossRef]

43. Kirchherr, J.; Reike, D.; Hekkert, M. Conceptualizing the circular economy: An analysis of 114 definitions. Resour. Conserv. Recycl. 2017, 127, 221-232. [CrossRef]

44. Mirata, M. Experience from early stages of a national industrial symbiosis programme in the UK: Determinants and coordi-nation challenges. J. Clean. Prod. 2004, 12, 967-983. [CrossRef]

45. Ghaffar, S.H.; Burman, M.; Braimah, N. Pathways to circular construction: An integrated management of construction and demolition waste for resource recovery. J. Clean. Prod. 2020, 244, 118710. [CrossRef]

46. Taboada, G.L.; Seruca, I.; Sousa, C.; Pereira, Á. Exploratory data analysis and data envelopment analysis of construction and demolition waste management in the european economic area. Sustainability 2020, 12, 4995. [CrossRef]

47. Zaman, A.U. A comprehensive review of the development of zero waste management: Lessons learned and guidelines. J. Clean. Prod. 2015, 91, 12-25. [CrossRef]

48. Zaman, A.U.; Lehmann, S. Challenges and opportunities in transforming a city into a "zero waste city". Challenges 2011, 2, 73-93. [CrossRef]

49. DiCicco-Bloom, B.; Crabtree, B.F. The qualitative research interview. Med. Educ. 2006, 40, 314-321. [CrossRef]

50. Gonzalez, C. Conceptions of, and approaches to, teaching online: A study of lecturers teaching postgraduate distance courses. High. Educ. 2009, 57, 299-314. [CrossRef]

51. Guest, G.; Bunce, A.; Johnson, L. How many interviews are enough? An experiment with data saturation and variability. Field Methods 2006, 18, 59-82. [CrossRef]

52. The Academic Triangle (20 March 2015). Available online: https://researcholic.wordpress.com/2015/03/20/sample_size_ interviews/ (accessed on 3 March 2020).

53. Gartenstein, D. Short-Term, Medium-Term \& Long-Term Planning in Business; 18 October 2018. Business Ideas. Available online: https: / / bizfluent.com/info-8277810-shortterm-mediumterm-longterm-planning-business.html (accessed on 2 March 2020).

54. Wu, Z.; Yu, A.T.; Shen, L. Investigating the determinants of contractor's construction and demolition waste management behavior in Mainland China. Waste Manag. 2017, 60, 290-300. [CrossRef] [PubMed] 